\title{
Plasma cortisol levels in captive wild felines after chemical restraint
}

G.P. Nogueira and J.C.R. Silva
Departamento de Apoio, Produção e Saúde Animal, Faculdade de Odontologia de Araçatuba,

Universidade Estadual de São Paulo, Araçatuba, SP, Brasil

\begin{abstract}
Correspondence
G.P. Nogueira

Departamento de Apoio, Produção e

Saúde Animal

Faculdade de Odontologia, UNESP

16050-680 Araçatuba, SP

Brasil

Fax: 55 (018) 622-2638

E-mail: guilherme@infocenter.com.br

Research supported by FAPESP and VRA-FMVZ-USP.

Presented at the XII Annual Meeting of the Federação de Sociedades de Biologia Experimental, Caxambu, MG, Brasil, August 27-30, 1997.
\end{abstract}

Received April 10, 1997 Accepted August 19, 1997 $\ldots \ldots \ldots \ldots \ldots \ldots \ldots$
Abstract

Eight Panthera onca $(\mathrm{Po}), 13$ Felis concolor $(\mathrm{Fc}), 7$ Felis yagouaroundi (Fy), 7 Felis tigrina $(\mathrm{Ft})$ and 5 Felis pardalis $(\mathrm{Fp})$ specimens from São Paulo State zoos were used. All animals were restrained with darts containing $10 \mathrm{mg} / \mathrm{kg}$ ketamine and $1 \mathrm{mg} / \mathrm{kg}$ xylazine. Venous blood samples were collected as soon as possible (within 15-20 min) and serum was frozen until the time for cortisol quantification. Cortisol was determined using a solid phase radioimmunoassay with an intraassay coefficient of $8.51 \%$. Data were analyzed statistically by the Kruskal-Wallis test, followed by Dunn's multiple comparisons test, and the one-sample $t$-test, with the level of significance set at $\mathrm{P}<0.05$. Data are reported as means \pm SEM. Cortisol levels differed among the captive felines: $\mathrm{Po}=166 \pm 33^{\mathrm{a}}, \mathrm{Fc}=670 \pm 118^{\mathrm{b}}, \mathrm{Fy}=480 \pm 83^{\mathrm{b}}, \mathrm{Ft}=$ $237 \pm 42^{\text {ab }}, \mathrm{Fp}=97 \pm 12^{\mathrm{a}} \mathrm{nmol} / \mathrm{l}$ (values followed by different superscript letters were significantly different $(\mathrm{P}<0.001))$. Since most of the veterinary procedures on these species involve chemical restraint, these results show the necessity of preventive measures in order to minimize the effect of restraint stress on more susceptible species.
Stress is defined as a change in homeostasis balance, usually resulting from environmental fluctuations. The animal's response to a stress stimulus may be divided into three phases: behavioral alteration, stimulation of the sympathetic system, and activation of the hypothalamic-pituitary adrenal (HPA) axis which results in a cortisol increase that can be measured to evaluate the stress response (1). Physical or chemical restraint is potentially the most stressful situation for a wild animal held in captivity (2). The method most often used for the examination of a large wild cat is chemical restraint. This procedure is necessary to insure the safety of the medical team and of the
Key words - Wild felines

- Plasma cortisol

- Captive felines animal during a medical intervention. Basic knowledge about the biology of the species is necessary for efficient restraint and examination of wild animals. A significant increase in plasma cortisol has been observed in cats up to $20 \mathrm{~min}$ after the beginning of the experiment (3). The administration of ACTH was followed by an increase of 160 to $1360 \%$ in cortisol levels (4). The cats did not show a circadian rhythm of cortisol secretion $(5,6)$. The present study was conducted in order to determine cortisol levels in captive wild felines submitted to the ketamine/xylazine restraint usually performed at zoos.

Forty adult captive felines from different São Paulo State zoos were used: 8 Panthera 
Table 1 - Serum cortisol levels of captive felines 15-20 min after chemical restraint with ketamine $(10 \mathrm{mg} / \mathrm{kg}) / x y l a z i n e ~(1$ $\mathrm{mg} / \mathrm{kg}$ ) at different São Paulo State zoos.

Data are reported as means \pm SEM for $\mathrm{N}$ animals. Values followed by different superscript letters were significantly different $(P<0.001)$.

\begin{tabular}{lc}
\hline Species & Serum cortisol $(\mathrm{nmol} / \mathrm{l})$ \\
\hline Panthera onca $(\mathrm{N}=8)$ & $166 \pm 33^{\mathrm{a}}$ \\
Felis concolor $(\mathrm{N}=13)$ & $670 \pm 118^{\mathrm{b}}$ \\
Felis yagouaroundi $(\mathrm{N}=7)$ & $480 \pm 83^{\mathrm{b}}$ \\
Felis tigrina $(\mathrm{N}=7)$ & $237 \pm 42^{\mathrm{ab}}$ \\
Felis pardalis $(\mathrm{N}=5)$ & $97 \pm 12^{\mathrm{a}}$ \\
Average & $333 \pm 47$
\end{tabular}

onca $(\mathrm{Po}), 13$ Felis concolor $(\mathrm{Fc}), 7$ Felis yagouaroundi $(\mathrm{Fy}), 7$ Felis tigrina $(\mathrm{Ft})$, and 5 Felis pardalis $(\mathrm{Fp})$. All animals were restrained with darts with a short range tranquilizer blowgun and projectile syringes containing $10 \mathrm{mg} / \mathrm{kg}$ ketamine and $1 \mathrm{mg} / \mathrm{kg}$ xylazine. As soon as the animals fell, within 15-20 min, venous blood samples were collected and serum was frozen until the time for cortisol quantification with a solid phase radioimmunoassay kit (DPC, Coat-a-Count, Los Angeles, CA) at VRA-FMVZ-USP, with an intra-assay coefficient of $8.51 \%$ and sensitivity of $1.48 \mathrm{nmol} / \mathrm{l}$. Data were analyzed statistically by the Kruskal-Wallis test to compare all animals, followed by Dunn's multiple comparisons test, and by the onesample $t$-test to compare the mean of one species with a domestic cat reference, with the level of significance set at $\mathrm{P}<0.05$. Data are reported as means \pm SEM.

The results are shown in Table 1. Significant differences in cortisol levels were observed both between $(\mathrm{P}<0.001)$ and within
$(\mathrm{P}<0.05)$ species.

Minimal stress during restraint is one of the aims of the zoo staff. Restraint is one of the most stressing procedures for a captive animal, with several effects on its behavior and activities. Unfortunately, the response to stress can be highly diverse among species and indeed among individuals within a species. The measurement of cortisol secretion is a reliable method to evaluate the response of the animals to a stress stimulus.

After the administration of $\mathrm{ACTH}(4,7,8)$ or physical restraint (3), maximal cortisol secretion was observed within 30 and $60 \mathrm{~min}$ in the felines. The mean plasma cortisol level observed in this experiment was $333 \pm$ $47 \mathrm{nmol} / \mathrm{l}$, a much higher value than observed in normal domestic cats, i.e., $35 \mathrm{nmol} /$ 1 (9) and $87 \pm 16 \mathrm{nmol} / \mathrm{l}$ (3). Po and Fp showed lower cortisol levels and Fc higher cortisol levels when compared with domestic cats $(298 \mathrm{nmol} / \mathrm{l})$ after $i v$ administration of cosyntropin, a synthetic ACTH (10).

When compared with the plasma cortisol levels reported elsewhere (11) and considering that maximal cortisol secretion may occur 30 to $60 \mathrm{~min}$ after the stimulus, it was impossible to detect baseline levels. We now intend to evaluate the adrenal response to ACTH in each species, and to determine whether $\mathrm{Fc}$ has a faster activation of the HPA axis than the other wild felines evaluated or a higher stress response during restraint.

\section{Acknowledgments}

We are grateful to the zoos of Araçatuba, Bauru, Piracicaba, Sorocaba and Taboão da Serra, all in the State of São Paulo, Brazil. 


\section{References}

1. Fowler ME (1986). Stress. In: Zoo and Wild Animal Medicine. 2nd edn. W.B. Saunders, Philadelphia.

2. Pachaly JR, Werner PR, Schimanski JC \& Ciffoni EMG (1993). Estresse por captura e contenção em animais selvagens. A Hora Veterinária, 13: 47-52.

3. Willemse T, Vroom MV, Mol JA \& Rijnberk A (1993). Changes in plasma cortisol, corticotropin, and alpha-melanocyte-stimulating hormone concentrations in cats before and after physical restraint and intradermal testing. American Journal of Veterinary Research, 54: 69-72.

4. Sparkes AH, Adams DT, Douthwaite JA \& Gruffydd Jones TJ (1990). Assessment of adrenal function in cats: response to intravenous synthetic ACTH. Journal of Small Animal Practice, 31: 1-4.

5. Johnston SD \& Mather EC (1979). Feline plasma cortisol (hydrocortisone) measured by radioimmunoassay. American Journal of Veterinary Research, 40: 190192.
6. Leyva $H$, Addiego $L$ \& Stabenfeldt $G$ (1984). The effect of different photoperiods on plasma concentrations of melatonin, prolactin and cortisol in the domestic cat. Endocrinology, 115: 1729-1736.

7. Carlstead K, Brown JL, Monfort SL, Killens R \& Wildt DE (1992). Urinary monitoring of adrenal responses to psychological stressors in domestic and nondomestic felids. Zoo Biology, 11: 165-176.

8. Peterson ME \& Kemppainen RJ (1993). Dose-response relation between plasma concentrations of corticotropin and cortisol after administration of incremental doses of cosyntropin for corticotropin stimulation testing in cats. American Journal of Veterinary Research, 54: 300-304.

9. Peterson ME, Kemppainen RJ \& Orth DN
(1994). Plasma concentrations of immunoreactive proopiomelanocortin peptides and cortisol in clinically normal cats. American Journal of Veterinary Research, 55: 295-300.

10. Peterson ME \& Kemppainen RJ (1992). Comparison of intravenous and intramuscular routes of administering cosyntropin for corticotropin stimulation testing in cats. American Journal of Veterinary Research, 53: 1392-1395.

11. Carter KK, Chakraborty PK, Bush M \& Wildt DE (1984). Effects of electroejaculation and ketamine- $\mathrm{HCl}$ on serum cortisol, progesterone, and testosterone in the male cat. Journal of Andrology, 5: 431437. 